\title{
Analisis Industri Telekomunikasi Seluler di Indonesia: Pendekatan SCP (Structure Conduct Perfoemance)
}

\author{
Annuridya Rosyidta Pratiwi Octasylva * \\ Institut Teknologi Indonesia \\ Joko Rurianto \\ Institut Pertanian Bogor \\ *Email:octasylva@gmail.com
}

\begin{abstract}
Abstrak
Industri telekomunikasi di Indonesia terus bergerak seiring dengan bertambahnya jumlah penduduk serta meningkatnya jumlah pengguna telepon seluler pada beberapa tahun terakhir. Peningkatan jumlah pelanggan tersebut diikuti dengan bertambahnya jumlah operator seluler yang memasuki industri. Pendekatan paradigma SCP (Structure-ConductPerformance) yang dilakukan pada penelitian ini memiliki tujuan untuk menganalisis struktur, perilaku, dan kinerja industri telekomunikasi Indonesia secara terstruktur dan komprehensif. Struktur pasar akan dilihat dari jumlah pelanggan, market share antara operator, serta entry barrier. Perilaku industry dapat terlihat dari strategi korporasi melalui strategi produk, strategi bersaing, strategi pemasaran, dan analisa biaya investasi (CAPEK - OPEX) masing-masing perusahaan. Sedangkan kinerja industri dinilai melalui rasio likuiditas, profitabilitas, maupun leverage. Hasil penelitian menunjukkan bahwa struktur pasar pada industri telekomunikasi dalam hal ini adalah provider telepon seluar di Indonesia adalah jenis pasar oligopoli ketat. Perilaku industri yang tercermin pada strategi produk menunjukan bahwa inovasi merupakan hal penting dalam industri telekomunikasi. Kinerja industri telekomunikasi dengan parameter rasio ROA menunjukkan tingkat positif dengan PT Telekomunikasi Selular (Telkomsel) sebagai perusahaan yang memiliki nilai (ROA) Return on Asset paling tinggi dengan capaian nilai rerataannya pada industri telekomunikasi sebesar 25\% - 30\% selama 5 tahun terakhir.
\end{abstract}

Kata Kunci: industri telekomunikasi, kinerja, SCP(Structure Conduct Performance),

\section{Pendahuluan}

Pertumbuhan ekonomi dapar difiniskan sebagai proses bertambahnya output produksi dalam satu periode. Pertumbuhan ekonomi diukur menggunakan perolehan Produk Domestik Bruto (PDB) sebagai proses kenaikan jumlah output. Proses pertumbuhan ekonomi mencerminkan keadaan perekonomian sebuah negara dalam perjalanannya menuju kondisi yang semakin baik selama beberapa periode waktu tertentu sekaligus dapat mencerminkan kenaikan pendapatan nasional yang diperoleh oleh semua rumah tangga keluarga (RTK) sebuah negara dalam satu periode. Perkembangan ekonomi bisa digambarkan juga sebagai proses kenaikan kapasitas produksi yang diwujudkan dalam bentuk pendapatan nasional sebagai indikasi pembangunan ekonomi.

Pertumbuhan ekonomi suatu negara tidak terlepas dari pertumbuhan sektor industri. Keduanya saling berkaitan dan memiliki hubungan positif yang ditunjukkan dengan kenaikan pertumbuhan sektor industri, maka secara langsung dapat mendorong pertumbuhan ekonomi suatu negara. Pertumbuhan PDB tentu juga diikuti oleh sektor-sektor yang membentuk PDB. Pada Gambar 1. dibawah dapat dilihat bahwa sektor industri pengolahan menyumbang lebih 
dari 20\% terhadap PDB selama 4 tahun secara beruntun. Hal ini menjadikan sektor Industri Pengolahan menjadi sektor yang utama dalam memberikan kontribusi terhadap PDB, diikuti dengan sektor Pertanian dan Perdagangan sebesar lebih dari 13\% Reparasi Mobil dan Sepeda Motor dengan angka diatas 13\%. Sedangkan sektor Pengadaan Air, Jasa Kesehatan \& Sosial, Pengadaan Listrik dan Gas menjadi yang terkecil dengan kontribusi di bawah $1 \%$.

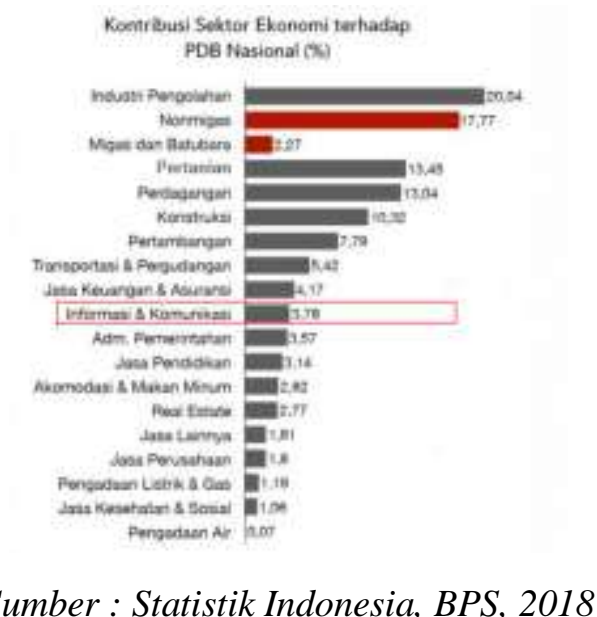

Gambar 1. Konstribusi Sektor PDB Nasional 2018

Sektor Informasi dan Komunikasi menyumbang sekitar 3,78\% selama 4 tahun terakhir. Hal ini membuatnya terlihat kecil jika dibandingkan dengan sektor Industri Pengolahan dengan nilai hingga 20\%. Namun, dari capaian PDB selama 4 tahun terakhir (sumber BPS 2018) didapatkan informasi bahwa sektor komunikasi dan informasi menjadi salah satu sektor yang terus bertumbuh paling tinggi di kisaran $8 \%-10 \%$, dengan detail sebagai berikut :

Tabel 1. Pertumbuhan PDB Sektor Informasi dan Komunikasi Indonesia (Tahun 2014 2018)

\begin{tabular}{|c|l|l|l|l|l|l|}
\hline \multirow{2}{*}{$\begin{array}{c}\text { Sektor Informasi dan } \\
\text { Komunikasi }\end{array}$} & $\mathbf{2 0 1 4}$ & $\mathbf{2 0 1 5}$ & $\mathbf{2 0 1 6}$ & $\mathbf{2 0 1 7}$ & $\mathbf{Q 1 ~ 2 0 1 8}$ & Q2 2018 \\
\cline { 2 - 7 } & $10.12 \%$ & $9.7 \%$ & $8.88 \%$ & $9.81 \%$ & $8.52 \%$ & $10.14 \%$ \\
\hline
\end{tabular}

Sumber : Statistik Indonesia, BPS, 2018

\section{Konstribusi Sektor Telekomunikasi di Indonesia Semester 12018}

Sektor Informasi dan Komunikasi adalah sektor pendukung PDB dengan kecepatan pertumbuhan yang lebih tinggi dibandingkan sektor lainnya. Berdasarkan data dari BPS, kontribusi yang berasal dari sektor Informasi dan Komunikasi mengalami kenaikan pada setiap tahunnya dengan detail sebagai berikut :

\section{Q1 2018}

Lapangan Usaha Informasi dan Komunikasi triwulan I/2018 (y-on-y) tumbuh sebesar 8,52 persen. Hal ini disebabkan oleh peningkatan Base Transceiver Station (BTS) 4G di beberapa Industri telekomunikasi dan belanja iklan di media elektronik. Pada pertumbuhan triwulan I/2018 dibandingkan dengan triwulan IV/2017 (q-to-q), lapangan Usaha Informasi dan Komunikasi tumbuh melambat dengan nilai $1,05 \%$. Hal ini salah satunya dipengaruhi oleh 
peraturan mengenai peraturan registrasi, dimana pemblokiran bagi penggunaan telepon seluler yang tidak mendaftarkan nomor dengan Nomor Induk Keluarga dan Kartu Keluarga.

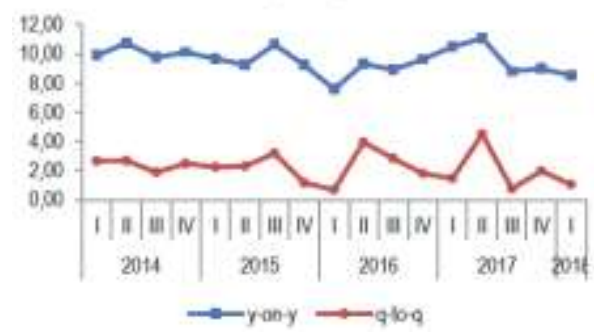

Sumber : Statistik Indonesia, BPS, 2018

Gambar 2. Kontribusi Sektor Komunikasi dan Pariwisata Q1 2018

\section{Q2 2018}

Kinerja Lapangan Usaha Informasi dan Komunikasi triwulan II/2018 (y-on-y) tumbuh sebesar 6,06 persen. Hal ini disebabkan adanya perluasan infrastruktur fiber optic dan Base Transceiver Station (BTS) 4G sesuai arah strategi perusahaan menuju digital company. Dibandingkan dengan triwulan I/2018 (q-to-q), Lapangan Usaha Informasi dan Komunikasi pada triwulan II/2018 tumbuh sebesar 2,13 persen. Hal ini tercermin dari adanya peningkatan trafik data dan penggunaan mobile internet selama periode lebaran di hampir semua Industri seluler. Secara kumulatif hingga triwulan II/2018 (c-to-c) kinerja Lapangan Usaha Informasi dan Komunikasi tumbuh sebesar 7,26 persen, hal ini salah satunya dipengaruhi oleh pembangunan BTS 4G yang berdampak penambahan jumlah pelanggan selama semester I/2018 dan meningkatnya pendapatan iklan.

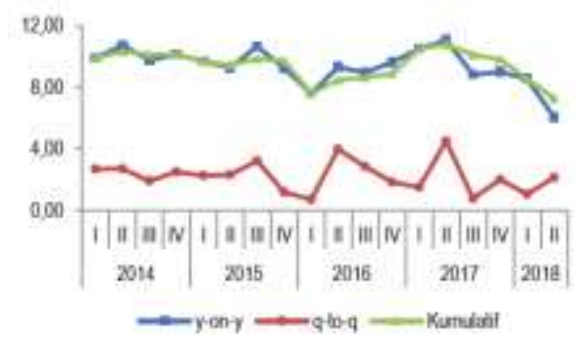

Sumber : Statistik Indonesia, BPS, 2018

Gambar 3. Kontribusi Sektor Komunikasi dan Pariwisata Q2 2018

\section{Industri Telekomunikasi}

Sektor Informasi dan Komunikasi erat hubungannya dengan Industri seluler dan pasar seluler. Pesatnya pertumbuhan industri telekomunikasi seluler didorong oleh perkembangan yang pesat dari pasar telepon seluler (Adiningsih, 2007). Sektor Informasi dan Komunikasi adalah komoditas yang krusial dalam kehidupan masyarakat. Telekomunikasi telah menjadi kebutuhan primer masyarakat. Dengan menggunakan fasilitas telekomunikasi masyarakat medapatkan kemudahan dalam menjalani berbagai aktivitas dalam kehidupannya. 


\section{Annuridya Rosyidta Pratiwi Octasylva, Joko Rurianto}

Perusahaan-perusahaan yang pernah bersaing di dalam industri telekomunikasi antara lain adalah XL Axiata, Indosat Ooredoo (Indosat), Telkomsel, Telkom Indonesia (Flexi), Hutchison Tri Indonesia (3), Smart Telecom (Smart), Bakrie Telecom, Sampoerna Telekomunikasi Indonesia (Ceria), Mobile-8 Telecom (Fren), AXIS Telekom Indonesia (AXIS), dan sebagainya. Namun dikarenakan kettnya persaingan saat ini, perusahaanperusahaan telekomunikasi seluler di Indonesia menyisakan lima perusahaan antara lain Telkomsel, XL Axiata, Indosat Ooredoo, Smartfren, dan Hutchison Tri (3).Satu hal lain yang menarik adalah akibat kebijakan pemerintah tentang pemerintah mengenai kartu prabayar dengan validasi data dukcapil (Kebijakan Peraturan Menteri Kominfo Nomor 14 Tahun 2017) serta gencarnya perang tarif para Industri yang makin gencar, dan juga tuntutan pelanggan terhadap kualitas layanan yang semakin baik sehingga perlu dilakukan analisa terhadap berbagai macam strategi atau perilaku yang dapat dilakukan oleh perusahaan, sehingga peneliti tertarik untuk meneliti mengenai Analisis Stucture Conduct Performance (SCP) pada industri telekomunikasi di Indonesia.

\section{Landasan Teori dan Pengembangan Hipotesis}

Struktur dan kondisi pasar merupakan kunci pada keberhasilan suatu bisnis. Pada Teori Industrial Organization Church, J., \& Ware, R. (2000). berisi beberapa aspek yang berdampak pada keputusan dan perilaku perusahaan, di mana sejak saat itu, diasumsikan bahwa "perilaku bergantung pada konteks di mana perilaku itu terjadi”.

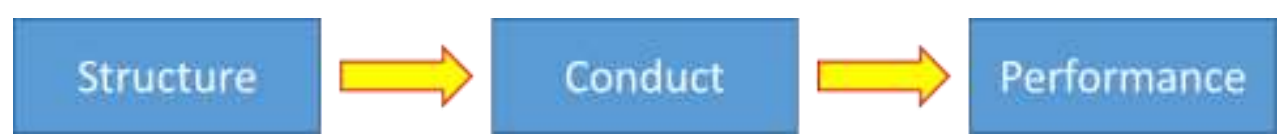

Gambar 4. Logika Dasar SCP

$$
\text { Sumber : Brown (2002) }
$$

Asumsi logika dasar SCP yaitu adanya hubungan sebab akhibat antara struktur dan kinerja. Sehingga, perilaku dan kinerja perusahaan tidak berdampak pada struktur pasar. Ketika ada efek umpan balik dalam paradigma SCP sebuah industri, penyebab hubungan antara struktur dan kinerja hilang. Oleh karena itu, sangat memungkinkan bagi perusahaan untuk memengaruhi. Asumsi yang mendasari modelnya adalah paradigma Neoklasik . Berdasarkan pendekatan Industrial Organization, kinerja suatu industri dipengaruhi oleh conduct (perilaku) dari perusahaan, yang mana ini juga bergantung dari struktur (faktor yang menentukan competitiveness dari pasar). Struktur dari industri bergantung dari kondisi dasar, seperti teknologi ataupun demand dari produk. Pendekatan SCP merupakan cara yang generik untuk mengatur studi dari industrial organization Carlton \& Perloff (2000).

\section{HHI (Herfindahl Hirschman Index)}

Indeks Herfindhal merupakan ukuran konsentrasi dan dapat didefinisikan sebagai jumlah pangkat dua pangsa pasar dari seluruh perusahaan yang ada dalam suatu industri, dan diformulasikan:

$\mathrm{H}=\mathrm{P} 1^{\wedge} 2+\mathrm{P} 2^{\wedge} 2+\mathrm{P}^{\wedge} 2+\ldots+\mathrm{PN}^{\wedge} 2$

Nilai $\mathrm{H}$ adalah antara 0 sampai denngan 1 . Jika, nilai $\mathrm{H}=1 / \mathrm{n}$ jika terdapat $\mathrm{n}$ perusahaan yang mempunyai ukuran yang sama. Jika $\mathrm{H}$ mendekati nol, maka akan berarti terdapat 
sejumlah besar perusahaan dengan ukuran usaha yang hampir sama dalam industri, dan konsentrasi pasar adalah rendah Diallo, A., \& Tomek, G. (2015). Sebaliknya, industri bersifat monopoli jika $\mathrm{H}$ sama dengan satu. Semakin tinggi $\mathrm{H}$, semakin tinggi disribusi ukuran dari perusahaan. The Federal Trade and Commission in the US menetapkan bahwa pasar terkategori highly concentrated jika nilai $\mathrm{H}$ lebih besar dari 0.18 (Chiang 2001). Hirschman-Herfindhal Index dirumuskan sebagai :

$$
\mathrm{HHI}=\sum_{\mathrm{i}=1}^{\mathrm{n}} \mathrm{Si}^{2}
$$

Dimana :

$\mathrm{Si} \quad=$ Presentase dari total penjualan dalam suatu industri

$\mathrm{N} \quad=$ Jumlah perusahaan yang diamati.

\section{Hambatan untuk Masuk (Barrier to Entry)}

Hambatan masuk pasar dapat dilihat dari mudah atau tidaknya pesaing-pesaing potensial untuk masuk ke pasar. Semakin tinggi barrier to entry maka akan semakin lemah ancaman dari pendatang baru yang hendak masuk ke dalam suatu industri. Cara yang digunakan untuk melihat hambatan masuk adalah dengan menggunakan skala ekonomis yang didekati melalui output perusahaan yang menguasai pasar lebih dari 50 persen. Nilai output tersebut kemudian dibagi dengan total output industri. Data ini disebut sebagai Minimum Efficiency Scale (MES), (Jaya, 2001).

$$
\text { MES }=\frac{\text { Output perusahaan terbesar }}{\text { Output total }} \times 100 \%
$$

Semakin tinggi nilai MES, maka hambatan untuk memasuki pasar akan semakin sulit pula. Nilai MES yang lebih dari 10 persen menggambarkan hambatan masuk pasar yang tinggi pada suatu industri.

\section{Ratio Konsentrasi (CR)}

Rasio Konsentrasi (concentration ratio, CR) secara luas dipergunakan untuk mengukur pangsa pasar dari output, turnover, jumlah pegawai atau nilai asset dari total industri. Rasio konsentrasi dapat digunakan untuk mengukur struktural power karena melibatkan jumlah absolute perusahaan dan ukuran distribusi. CR yang di definisikan sebagai presentase dari keseluruhan output industri yang dihasilkan oleh perusahaan terbesar. Biasanya jumlah perusahaan $\mathrm{N}$ yang dihitung proporsi pangsa pasarnya adalah 4 , sehingga dikenal sebagai CR4. Jika Pi mewakili pangsa pasar, dan jika proporsi dari output, turnover, jumlah pegawai atau nilai asset dari total industri yang diwakili oleh perusahaan $\mathrm{i}=1,2, \ldots$, dengan $\mathrm{P} 1>=\mathrm{P} 2>=\mathrm{P} 3$ $>=\ldots$, maka Concentration Ratio, CRN, untuk N perusahaan dihitung sebagai:

$$
\mathrm{CRN}=\mathrm{P} 1+\mathrm{P} 2+\mathrm{P} 3+\ldots+\mathrm{PN}
$$

Rasio konsentrasi dirumuskan sebagai berikut :

Rantio kansertrasi $-\sum_{\mathrm{i}=1}^{\mathrm{n}} \frac{\mathrm{xi}}{\mathrm{T}}$

Dimana :

$\mathrm{n} \quad=$ Jumlah perusahaan yang dipilih berdasarkan peringkat penjualan terbesar.

$\mathrm{Xi} \quad=$ Besarnya angka penjualan dari perusahaan yang dipilih 
$\mathrm{T}=$ Total penjualan dalam industri.

Rasio konsentrasi berkisar antara nol hingga satu dan biasanya dinyatakan dalam persentase. Nilai konsentrasi yang mendekati angka nol mengindikasikan bahwa sejumlah $n$ perusahaan memiliki pangsa pasar yang relatif kecil. Sebaliknya, angka rasio konsentrasi yang mendekati satu mengindikasikan tingkat konsentrasi yang relatif tinggi.

\section{Metode Penelitian}

Metode penelitian yang digunakan disini merupakan analisa deksriptif dan kualitatif dengan menggunakan dana sekunder. Menurut Indriantoro (2002) penelitian deskriptif adalah penelitian yang menggambarkan suatu fenomena dengan jalan mendeskripsikan sejumlah variabel yang berkenaan dengan masalah yang diteliti. Penelitian kuantitatif yaitu penelitian yang menggunakan data berbentuk angka-angka yang empiris, terukur dan teramati. Penelitian kuantitatif juga digunakan untuk membuktikan atau menolak suatu teori.

\section{Pembahasan}

\section{Analisis SCP Industri Telekomunikasi}

\section{Analisis Struktur}

Struktur industri telekomunikasi di Indonesia antara lain dapat dilihat dengan parameter sebagai berikut :

- Herfindahl Hirschman Index (HHI).

- Ratio Konsentrasi (CR).

- Minimum Efficiency of Scale (MES).

A. Menghitung nilai Herfindahl Hirschman Index (HHI)

Berdasarkan perhitungan market share kuadrat dari masing-masing Industri seluler, dapat dihitung nilai jumlah pangsa pasar (market share) dan HHI dari industri telekomunikasi Indonesia, hasil yang diperoleh adalah sebagai berikut :

Tabel 2. Data Market Share Industri Telekomunikasi

\begin{tabular}{|l|r|r|}
\hline \multicolumn{1}{|c|}{ Nama Perusahaan } & \multicolumn{1}{c|}{ Jumlah Pelanggan Selular (juta) } & \multicolumn{1}{c|}{ Jumlah pangsa pasar } \\
\hline PT Telekomunikasi Selular & 168.6 & $52.97 \%$ \\
\hline PT XL Axiata Tbk & 55.1 & $17.31 \%$ \\
\hline PT Indosat Tbk & 53.3 & $8.75 \%$ \\
\hline PT Hutchison 3 Indonesia & 26.2 & $4.74 \%$ \\
\hline PT Smartfren Telecom Tbk & 15.1 & $100.00 \%$ \\
\hline Total & & \\
\hline
\end{tabular}

Sumber : Laporan keuangan tahunan (data diolah) 
INOBIS: Jurnal Inovasi Bisnis dan Manajemen Indonesia

Volume 03, Nomor 03, Juni 2020

Annuridya Rosyidta Pratiwi Octasylva, Joko Rurianto

Menghitung nilai HHI :

Tabel 3. Nilai HHI Industri Telekomunikasi

\begin{tabular}{|l|r|r|}
\hline \multicolumn{1}{|c|}{ Nama Perusahaan } & Market Share & \multicolumn{1}{|c|}{ MS^2*10000 $^{\wedge}$} \\
\hline PT Telekomunikasi Selular & $50.54 \%$ & 2,806 \\
\hline PT XL Axiata Tbk & $16.52 \%$ & 300 \\
\hline PT Indosat Tbk & $15.98 \%$ & 280 \\
\hline PT Hutchison 3 Indonesia & $7.85 \%$ & 23 \\
\hline PT Smartfren Telecom Tbk & $4.53 \%$ & 3,476 \\
\hline HHI & & \\
\hline
\end{tabular}

Sumber : Laporan keuangan tahunan (data diolah)

Analisa HHI dalam penelitian ini mengunakan pendekatan jumlah pelanggan dari penyelenggara seluler. Berdasarkan perhitungan nilai HHI dari data pelanggan (update Q1 2019), maka dapat dilihat bahwa market share Telkomsel mencapai 50.54\%, XL Axiata $16.52 \%$, dan Indosat $15.98 \%$. Nilai HHI industri Telekomunikasi di Indonesia mencapai 3,476 $\sim 0.35$, yang menunjukkan bahwa industri telekomunikasi memiliki konsentrasi pasar yang tinggi (>0.18).

B. Menghitung nilai Ratio Konsentrasi (CR)

Perhitungan nilai CR dapat terlihat dari table 4.

Tabel 4. Data Nilai CR Industri Telekomunikasi

\begin{tabular}{|l|r|r|}
\hline \multicolumn{1}{|c|}{ Nama Perusahaan } & Jumlah Pelanggan Selular (juta) & Jumlah pangsa pasar \\
\hline PT Telekomunikasi Selular & 168.6 & $52.97 \%$ \\
\hline PT XL Axiata Tbk & 55.1 & $17.31 \%$ \\
\hline PT Indosat Tbk & 53.3 & $16.75 \%$ \\
\hline PT Hutchison 3 Indonesia & 26.2 & $8.23 \%$ \\
\hline TOTAL & & $95.26 \%$ \\
\hline
\end{tabular}

Sumber : Laporan keuangan tahunan (data diolah)

Berdasarkan data yang tercantum di dalam tabel maka kita dapat melihat 4 perusahaan terbesar yang ada dalam industri ini memiliki pangsa pasar yang bervariasi dengan jumlah keseluruhan sebesar 95,26\%. Dari angka tersebut dapat juga diketahui bahwa industri telekomunikasi memiliki struktur pasar oligopoli ketat, karena market share dari 3 perusahaan itu snediri berada diantara $60 \%$ sampai dengan $100 \%$, hal ini menyebabkan kesempatan diantara mereka untuk menetapkan harga relatif lebih mudah. 
INOBIS: Jurnal Inovasi Bisnis dan Manajemen Indonesia

Volume 03, Nomor 03, Juni 2020

Annuridya Rosyidta Pratiwi Octasylva, Joko Rurianto

\section{Menghitung nilai Minimum Efficiency of Scale (MES)}

Nilai MES dapat diperoleh dari perbandingan output perusahaan terbesar dengan jumlah output total. Perusahaan terbesar dalam industri telekomunikasi di Indonesia adalah PT Telekomunikasi Selular. Dibawah ini merupakan tabel nilai Minimum Efficiency of Scale (MES) industri telekomunikasi periode 2014 sampai dengan 2019.

Tabel 5. Data MES Industri Telekomunikasi

\begin{tabular}{|r|r|r|r|}
\hline Tahun & \multicolumn{2}{|c|}{$\begin{array}{c}\text { Nilai output perusahaan } \\
\text { terbesar (juta) }\end{array}$} & $\begin{array}{c}\text { Nilai output total } \\
\text { (juta) }\end{array}$ \\
\hline $\mathbf{2 0 1 4}$ & 140.6 & 287.01 & $48.99 \%$ \\
\hline $\mathbf{2 0 1 5}$ & 152.6 & 301.23 & $50.66 \%$ \\
\hline $\mathbf{2 0 1 6}$ & 163.7 & 325.43 & $50.30 \%$ \\
\hline $\mathbf{2 0 1 7}$ & 196.3 & 345.21 & $56.86 \%$ \\
\hline $\mathbf{2 0 1 8}$ & 140.1 & 301.94 & $46.40 \%$ \\
\hline $\mathbf{2 0 1 9}$ & 168.6 & 333.61 & $50.54 \%$ \\
\hline
\end{tabular}

Sumber : Laporan keuangan tahunan (data diolah)

Melalui pendekatan Minimum Effisiency Scale (MES) dapat diketahui besarnya persentase hambatan untuk masuk pasar. Nilai MES yang diperoleh dengan cara membagi nilai output terbesar perusahaan dengan total output dalam industri. Sepanjang lima tahun terakhir dari tahun 2014 sampai dengan 2019, rata- rata nilai MES industri telekomunikasi di Indonesia mengalami pergerakan dari angka $46 \%$ - 56\% persen. Nilai MES terbesar terjadi pada tahun 2017 yaitu sebesar 56.86\%, namun di tahun berikutnya nilai MES mengalami penurunan sampai $10 \%$ menjadi $46.40 \%$ karena pada saat itu ada kebijakan dari pemerintah selaku regulator untuk melakukan verifikasi data pelanggan opertaror telekomunikasi sesuai dengan kartu identitas yang berlaku (misal KTP).

\section{Analisis Conduct}

Berdasarkan hasil analisis, struktur pasar industri telekomunikasi di Indonesia bersifat oligopoli ketat. Hal ini menimbulkan beberapa perilaku yang dilakukan oleh perusahaanperusahaan di industri tersebut. Perilaku yang dilakukan tersebut antara lain :

\section{A. Kebijakan Harga}

Industri telekomunikasi harus benar-benar memperhatikan kebijakan harga, karena pada struktur oligopoli sangat peka terhadap kebijakan harga pesaing sehingga terkadang memacu perang harga. Hal ini menimbulkan efek negative dalam jangka panjang, sehingga harus serius diperhatikan, contohnya pernah terjadi di tahun 2017, dimana tarif murah mampu mengerek jumlah pelanggan secara signifikan. Sayangnya, peningkatan trafik yang melonjak drastis tidak sepadan dengan pendapatan yang diterima. Alhasil, praktek jual rugi ini akan mengancam kondisi keuangan Industri. Bukan tak mungkin, Industri bisa jatuh dan ujungnya konsumen yang dirugikan. 
B. Kebijakan Produk

Berbicara mengenai produk, tidak bisa dilepaskan dari kata inovasi produk itu sendiri, hal ini sejalan dengan kebutuhan dan keinginan dari para pengguna layanan, dimana semakin meningkat kebutuhan pelanggan untuk suatu layanan maka perusahaan tentunya akan terus melalukan suatu inovasi dan perbaikan agar perusahaan dapat terus eksis dan berkembang.

Beberapa kebijakan produk yang dilakukan oleh industri telekomunikasi adalah sebagai berikut :

- Telkomsel sejak tahun 2017 mencanangkan bisnis baru dalam bentuk bisnis digital untuk mengantisipasi penurunan pendapatan yang cukup tajam di bisis legacy (telfon dan SMS).

- XL menyederhanakan produk prabayarnya hanya dengan satu produk, dari sebelumnya terdapat 2 produk (XL Bebas dan XL Jempol)

- Telkomsel, Indosat, \& XL bekerjasama menjalankan layanan three telco untuk mobile advertising, dimana pesaing sesunguhnya layanan mobile advertising adalah duopoly (Google \& Facebook), sehingga Industri telekomunikasi perlu duudk bersama untuk menghadapi hal tersebut. Industri telekomunikasi juga memiliki data data pelanggan yang tidak dimiliki oleh Google \& Facebook, sehingga jika data pelanggan ini diolah dengan baik menggunakan sistem big data akan menghasilkan kekuatan yang luar biasa.

\section{Analisa Produk Internet}

Salah satu produk unggulan dari industri telekomunikasi adalah produk internet, terkait dengan hal tersebut nPerf salah satu lembaga pemeringkat kualitas internet dari Perancis pada tahun 2018 melakukan testing produk untuk industri telekomunikasi di Indonesia. Riset terhadap hasil internet ini didasarkan pada 650 ribu kali uji coba kecepatan, streaming, dan browsing. Hal lain yang diukur adalah success ratio, download bitrate, upload bitrate, latency, browsing, and YouTube streaming.

Hasil yang didapatkan adalah sebagai berikut :

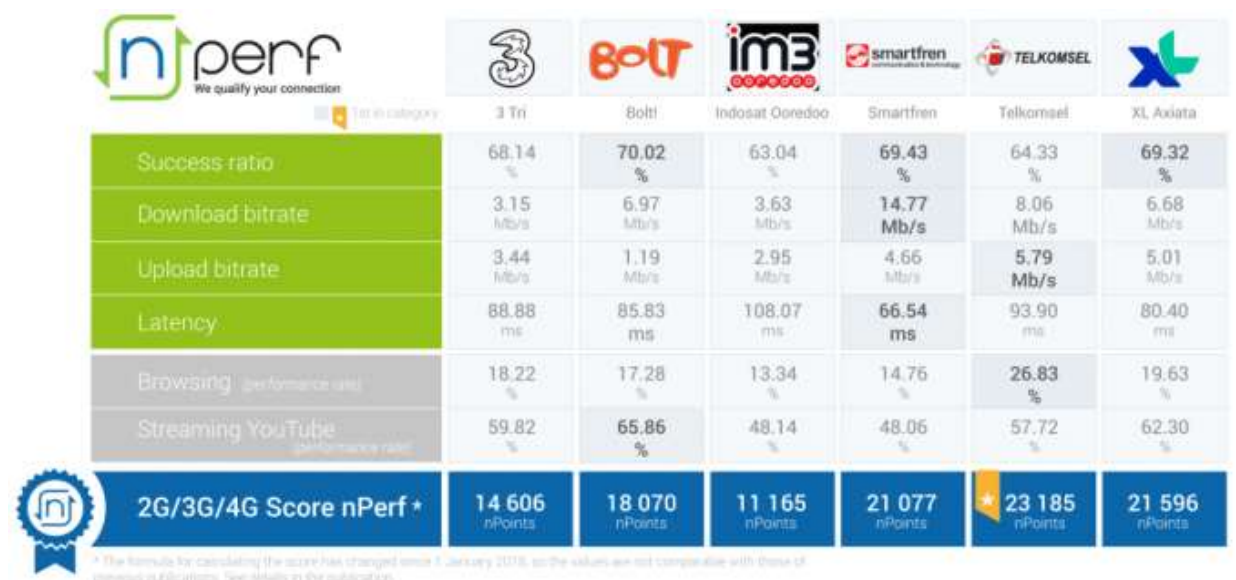

Gambar 6. Peringkat Kualitas Produk Internet 2018 Source : Survey nPerf 2018 
Hasilnya dapat dilihat di Gambar 6. Diatas. Telkomsel secara umum unggul dibandingkan pesaing, namun bukan yang terdepan dari semua aspek. Telkomsel unggul dalam hal bitrate upload and browsing. Di sisi lain, XL menjadi pesaing serius bagi semua industri telekomunikasi, khususnya produk internet di Indonesia. XL hanya sedikit di bawah Telkomsel di posisi kedua.

Dalam hal success ratio, XL memiliki 69,32\% dan Telkomsel adalah 64,33\%. XL juga melampaui Telkomsel dalam aspek streaming YouTube. Dalam hal success ratio sendiri, Smartfren secara umum memimpin dengan 69,43\% dan data download bitrate sebesar 14,77 $\mathrm{Mb} / \mathrm{s}$; angka ini bahkan mengalahkan Telkomsel (8.06 Mb/s) dan XL (6.68 Mb/s).Sementara itu Tri dan Indosat jauh di urutan kedua. 3 (Tri) mencatat kecepatan rata-rata download bitrate sebesar 3,15 Mb/s dan upload bitrate 3,44 Mb/s. Indosat, dengan download bitrate $6,97 \mathrm{Mb} / \mathrm{s}$ dan upload bitrate $1,19 \mathrm{Mb} / \mathrm{s}$.

\section{Kerjasama dengan pesaing}

Industri telekomunikasi juga sudah menerapkan mekanisme kerjasama antar pesaing sebagai salah satu strategi yang dijalankan, diantaranya adalah sebagai berikut :

\section{Network sharing}

Model kerja sama di mana sejumlah Industri telekomunikasi sebagai penyelenggara layanan, berbagi (shared) penggunaan infrastruktur jaringan telekomunikasi, meliputi infrastruktur pasif (passive sharing) dan infrastruktur aktif (active sharing), baik di sisi jaringan akses radio atau MORAN (Multi Industri Radio Access Network) maupun jaringan inti atau MOCN (Multi Industri Core Network).

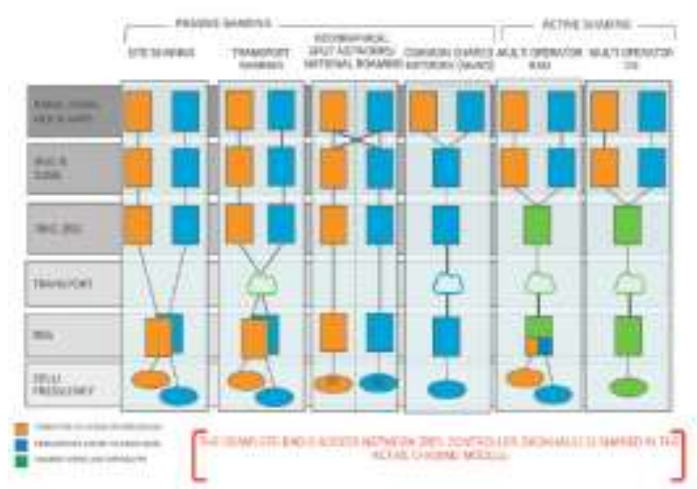

Gambar 7. Skema Network Sharing (Tereschuk, 2015)

Sumber : Statistik Indonesia, BPS, 2018

Menurut (GSM Association, 2012; Jose \& March, 2010), network sharing memberikan sejumlah manfaat di sisi konsumen dan industri itu sendiri, meliputi:

Sisi Konsumen:

- Tarif layanan menjadi lebih terjangkau dan variasi layanan semakin beragam;

- Tersebarnya jangkauan layanan telekomunikasi;

- Mendorong kompetisi antarindustri dalam membangun infrastruktur jaringan dan diferensiasi layanan, khususnya di wilayah yang masih minim atau belum terjangkau sama sekali oleh layanan telekomunikasi; 
INOBIS: Jurnal Inovasi Bisnis dan Manajemen Indonesia

Volume 03, Nomor 03, Juni 2020

Annuridya Rosyidta Pratiwi Octasylva, Joko Rurianto

Sisi industri :

- Penghematan biaya investasi pembangunan dan pemeliharaan infrastruktur jaringan sebesar 30-40 \%;

- Percepatan pembangunan infrastruktur, yang berakibat pada percepatan penetrasi pasar atau time to market;

- Risk sharing terkait dengan pembangunan dan pemeliharaan infrastruktur jaringan (contoh: izin pembangunan BTS baru).

Contoh penerapan network sharing :

PT Telekomunikasi Selular diamanatkan oleh pemerintah untuk menggelar infrastuktur 4G di seluruh Indonesia, termasuk di daerah 3T (Terluar, Terdepan, Tertinggal), dan biaya untuk menggelar layanan ini cukup mahal karena selain faktor tekhnologi juga jarak yang cukup jauh dan kondisi lapangan yang cukup berat. Sehingga Industri lain bisa menumpang network kepada PT Telekomunikasi Selular, tentu dengan skema bisnis yang disetujui oleh Operator lain dan PT Telekomunikasi Selular itu sendiri.

\section{Merger and Acquisition (M\&A)}

Merger dan Akuisisi merupakan perubahan ownership, gabungan bisnis, aset, dan aliansi dengan maksud untuk memaksimalkan nilai pemegang saham dan meningkatkan kinerja perusahaan (Pazarskis, Vogiatzogloy, Christodoulou, \& Drogalas, 2006). Sementara itu, jika dibedakan, masing-masing dapat didefinisikan bahwa merger merupakan proses menggabungkan dua perusahaan, di mana hanya ada satu yang bertahan dan tidak ada lagi entitas gabungan perusahaan (Gaughan, 2002), sedangkan akuisisi adalah proses yang terjadi ketika perusahaan melakukan pengambilalihan seluruh/sebagian saham perusahaan target, di mana perusahaan target tetap menjadi entitas yang sah (Nakamura, 2005). Contoh penerapan merger dan akuisisi yaitu, tahun 2014 AXIS Telekom Indonesia yang diakuisisi oleh XL Axiata Indonesia sebesar 865 juta dollar, serta tahun 2019 Telkomsel dan Bank-Bank BUMN (HIMBARA) bekerjasama membentuk PT Finarya dengan produk "Link Aja" yang khusus menyasar produk fintech (financial technology).

\section{Sistem Promosi \& Periklanan}

Bentuk- bentuk strategi komunikasi yang di lakukan operator telekomunikasi pada prinsipnya bertujuan agar efektif dan efisien untuk mencapai target audience yang di inginkan, bentuk-bentuk pemasaran ini merupakan misi dari program operator itu sendiri untuk mencapai sasaran dan memastikan implementasinya secara tepat, sehingga tujuan dan sasaran utama organisasi akan tercapai. Dalam mencapai keberhasilan pada proses pemasaran, maka beberapa program yang bisa dijalankan adalah sebagai berikut (Hughes \& Fill, 2005) :

- Advertising

- Sales Promotion

- Public Relation

- Personal Selling

- Direct Marketing (Pemasaran Langsung)

- Internet/Interactive Marketing 
E. Analisa Biaya Investasi (CAPEX - OPEX)

\section{Analisa CAPEX}

CAPEX (Capital Ependiture) adalah alokasi yang direncanakan (dalam anggaran) untuk melakukan pembelian/perbaikan/penggantian segala sesuatu yang dikategorikan sebagai aset perusahaan. Capex merupakan biaya-biaya yang digunakan oleh perusahaan untuk memperoleh atau menambah aktiva tetap atau aset fisik seperti properti, bangunan industri atau peralatan. Dibawah ini adalah detail alokasi CAPEX industri telekomunikasi selama 5 tahun terakhir :

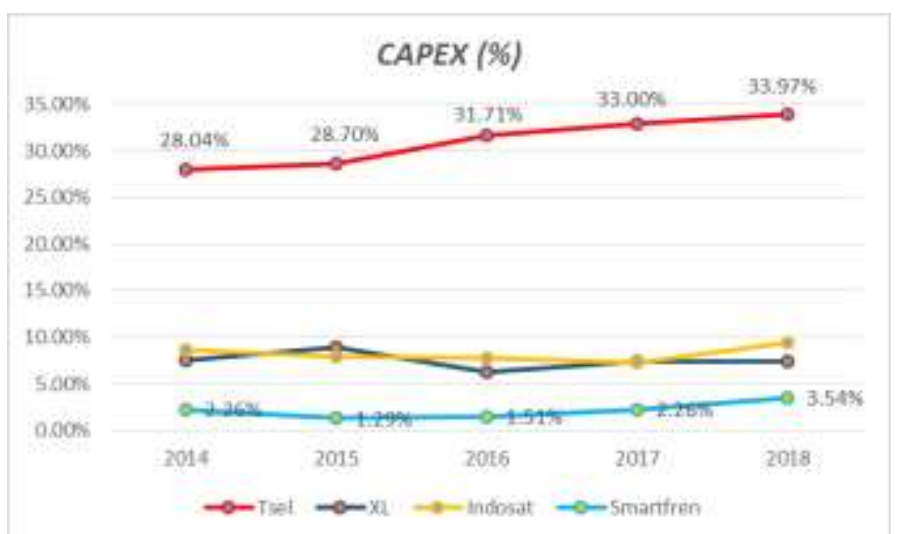

Gambar 8. Indikator CAPEX Industri Telekomunikasi (2014-2018)

Sumber : Laporan keuangan tahunan (data diolah)

Dari gambar 8. diatas dapat dilihat bahwa nilai CAPEX terbesar pada PT Telekomunikasi Selular sebesar 33.97\% pada tahun 2018, sedangkan besaran CAPEX terendah terdapat pada PT Smartfren Telecom Tbk, dengan nilai terendah pada tahun 2015 sebesar $1.29 \%$.

2. Analisa OPEX

OPEX (Operational Expendature) adalah alokasi anggaran (dalam anggaran) untuk melakukan operasional perusahaan. OPEX digunakan untuk menjaga kelangsungan aset dan menjamin aktivitas perusahaan, adapun nilai OPEX dapat terlihat pada gambar 9 .

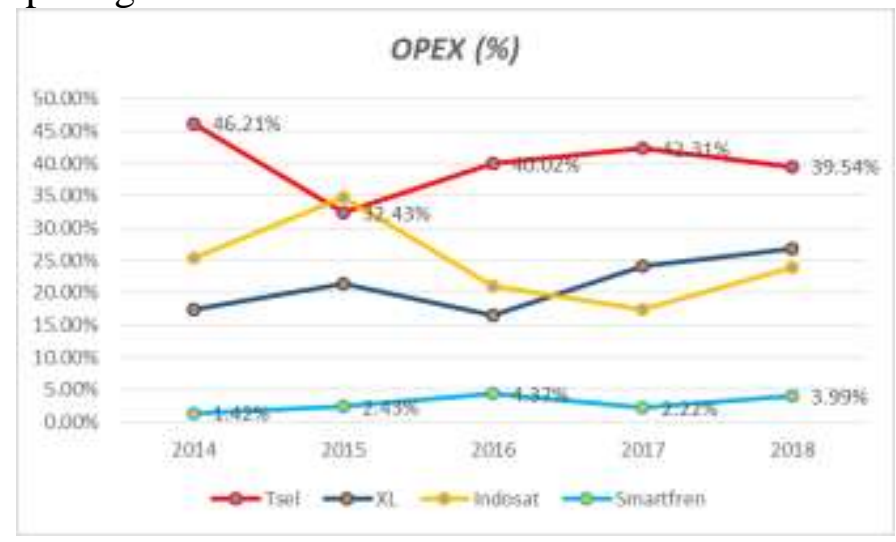

Gambar 9. Indikator OPEX Industri Telekomunikasi (2014-2018)

Sumber : Laporan keuangan tahunan (data diolah) 


\section{Analisis Performance}

Performance atau kinerja perusahaan, utamanya dilihat dari kinerja keuangan perusahaan, di mana ketika suatu perusahaan memiliki kinerja keuangan yang baik, maka berarti perusahaan tersebut dapat menjalankan operasional perusahaan dengan lebih efisien untuk menghasilkan profit dan menekan biaya.

Untuk mengukur profitabilitas pada penelitian ini peneliti menggunakan beberapa pendekatan, diantaranya adalah sebagai berikut :

1. Return on Assets (ROA) menunjukan kemampuan perusahaan menghasilkan laba dari total aktiva yang dipergunakan.

2. Debt to Equity Ratio merupakan perbandingan antara utang dengan ekuitas, semakin besar rasio ini, maka tidak baik bagi perusahaan.

3. Return on Equity (ROE) merupakan rasio perbandingan antara laba bersih dengan ekuitas.

4. Net Profit Margin merupakan rasio yang membandingkan antara laba bersih dengan penjualan perusahaan.

Tabel 6. dibawah menunjukkan kinerja keuangan operator telekomunikasi yang diambil dari laporan keuangan selama lima tahun terakhir, dengan detail sebagai berikut :

Tabel 6. Indikator Revenue Industri Telekomunikasi (2014-2018)

\begin{tabular}{|c|c|c|c|c|c|c|c|c|}
\hline \multirow{2}{*}{ Tahun } & \multicolumn{4}{|c|}{ Deb to Equity Ratio (\%) } & \multicolumn{4}{|c|}{ Return on Asset (\%) } \\
\hline & Tsel & $\mathrm{xt}$ & Indosat & Smartfren & Tsel & & Indosat & Smartfren \\
\hline 2014 & 15.30 & 2.10 & 2.75 & 3.48 & 25.60 & -5.70 & -3.49 & -7.77 \\
\hline 2015 & 20.70 & 1.90 & 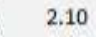 & 02 & 27,40 & -0.04 & -2. & 7.56 \\
\hline 016 & 10.60 & 0.7 & & 8 & 32.40 & 0.6 & & 8.65 \\
\hline 17 & 10.50 & 0.70 & & 61 & 34.60 & 0.70 & 20 & 0 \\
\hline 018 & 16.90 & 0.70 & 1.80 & 03 & 30.30 & -0.60 & $-4,5$ & -14.10 \\
\hline \multirow{2}{*}{ Tahun } & \multicolumn{4}{|c|}{ Return on Ec } & \multicolumn{4}{|c|}{ Net Profit $\mathrm{N}$} \\
\hline & rsel & $\mathrm{XL}$ & t & ren & rsel & & Indosat & tfren \\
\hline 014 & 38.58 & -5.70 & -13 & -34.81 & 29.21 & $1-14.30$ & 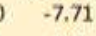 & 8 \\
\hline 2015 & 43.40 & -0.18 & -10 & 86 & 28.67 & -0.11 & -4 & 1.74 \\
\hline 2016 & 50.90 & 1.77 & 8.30 & -33.64 & 32.67 & $7 \quad 1.76$ & 80 & -54.28 \\
\hline 2017 & 53.60 & 1.70 & 10 & 2.70 & 33.41 & -1.60 & 3.80 & -64.70 \\
\hline & STo & 100 & 1.50 & -28.50 & 20.5 & 14.00 & 10.40 & $-64,70$ \\
\hline
\end{tabular}

Sumber : Laporan keuangan tahunan (data diolah)

1. Return on Asset (ROA)

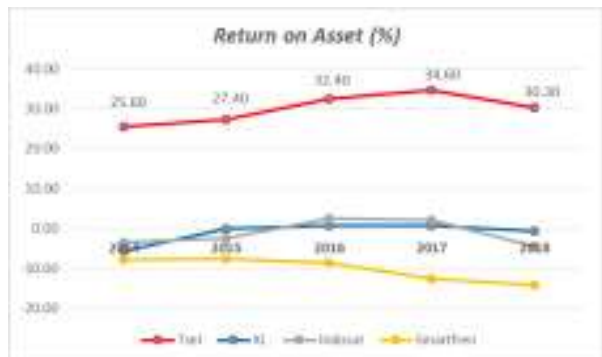

Gambar 10. Indikator ROA Industri Telekomunikasi (2014-2018)

Sumber : Laporan keuangan tahunan (data diolah) 
Return on Asset merupakan rasio yang membandingkan antara laba bersih dengan total aset. Semakin tinggi nilai rasio Return on Asset maka akan semakin baik. Rasio ini digunakan untuk melihat kemampuan perusahaan dalam mengelola setiap nilai asset yang dimiliki untuk menghasilkan laba bersih setelah pajak.

Tabel 7. Indikator ROA Industri Telekomunikasi (2014-2018)

\begin{tabular}{|l|r|r|r|r|r|}
\hline \multicolumn{1}{|c|}{ Data } & \multicolumn{1}{|c|}{$\mathbf{2 0 1 4}$} & \multicolumn{1}{c|}{$\mathbf{2 0 1 5}$} & \multicolumn{1}{c|}{$\mathbf{2 0 1 6}$} & \multicolumn{1}{c|}{$\mathbf{2 0 1 7}$} & \multicolumn{1}{c|}{$\mathbf{2 0 1 8}$} \\
\hline Rata - rata & 2.16 & 4.35 & 6.74 & 6.25 & 2.78 \\
\hline Standar Deviasi & 13.62 & 13.58 & 15.41 & 17.34 & 16.63 \\
\hline Minimum & -7.7 & -7.56 & -8.65 & -12.5 & -14.10 \\
\hline Maksimum & 25.60 & 27.40 & 32.40 & 34.60 & 30.30 \\
\hline
\end{tabular}

Sumber : Laporan keuangan tahunan (data diolah)

Dari gambar 10. di atas dapat dilihat dari tahun 2014-2018 PT. Smartfren Telecom Tbk merupakan perusahaan yang paling rendah nilai Return on Asset nya. Ini menandakan bahwa perusahaan sedang tidak baik, kemudian di susul oleh PT. Indosat Tbk, yang juga memiliki nilai Return on Asset yang rendah, lalu PT. XL Axiata Tb.

Dari tabel 8. diatas secara umum industri telekomunikasi memiliki nilai rata-rata yang positif selama 5 tahun terakhir, berarti bahwa bisnis menguntungkan (membuat keuntungan), karena menghasilkan pengembalian positif atas aset selama beberapa tahun berlangsung, dengan nilai ROA tertinggi ada pada tahun 2016 sebesar $6.74 \%$, dengan nilai standar deviasi 17.34. Nilai maksimum ROA sendiri didapatkan pada tahun 2017 dengan nilai 34.60\%.

\section{Debt to equity ratio (DER)}

Debt to Equity Ratio (rasio hutang modal) merupakan rasio yang digunakan untuk menilai utang dengan ekuitas. Rasio ini dicari dengan cara membandingkan antara seluruh utang, termasuk utang lancar dengan seluruh ekuitas. Rasio hutang modal menggambarkan sampai sejauh mana modal pemilik dapat menutupi hutang-hutang kepada pihak luar dan merupakan rasio yang mengukur hingga sejauh mana perusahaan dibiayai dari hutang. Semakin kecil rasio hutang modal maka semakin baik bagi perusahaan dan untuk keamanan pihak luar rasio terbaik jika jumlah modal lebih besar dari jumlah hutang atau minimal sama.

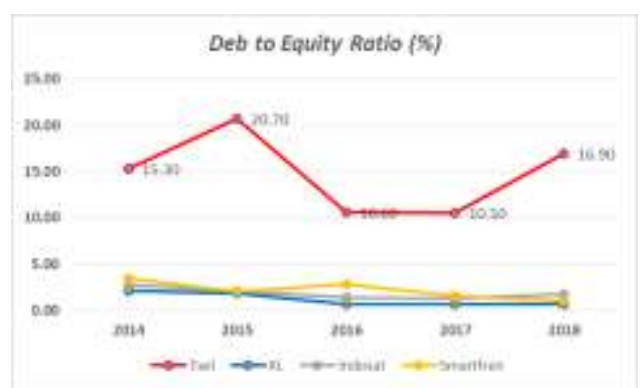

Gambar 11. Indikator DER Industri Telekomunikasi (2014-2018)

Sumber : Laporan keuangan tahunan (data diolah) 
Dari Gambar 11. di atas dapat dilihat bahwa semua perusahaan sampel memiliki nilai Debt to Equity Ratio yang baik dengan PT Telekomunikasi Selular memiliki DER yang paling tinggi dibandingkan dengan yang lain, dengan persebaran diantara $15 \%$ sampai dengan $20 \%$.

Tabel 8. Indikator DER Industri Telekomunikasi (2014-2018)

\begin{tabular}{|l|r|r|r|r|r|}
\hline \multicolumn{1}{|c|}{ Data } & $\mathbf{2 0 1 4}$ & $\mathbf{2 0 1 5}$ & $\mathbf{2 0 1 6}$ & $\mathbf{2 0 1 7}$ & $\mathbf{2 0 1 8}$ \\
\hline Rata - rata & 5.91 & 6.68 & 3.90 & 3.53 & 5.11 \\
\hline Standar Deviasi & 5.44 & 8.09 & 3.95 & 4.04 & 6.82 \\
\hline Minimum & 2.10 & 1.90 & 0.70 & 0.70 & 0.70 \\
\hline Maksimum & 15.30 & 20.70 & 10.60 & 10.50 & 16.90 \\
\hline
\end{tabular}

Sumber : Laporan keuangan tahunan (data diolah)

Dari tabel 8. diatas secara umum industri telekomunikasi selama 5 tahun terakhir, nilai rasio cenderung bergerak ke arah positif, di mana rata-rata DER tertinggi terjadi pada tahun 2015, yakni sebesar 6.68\% dengan standar deviasi 8.09\%. Return on Equity

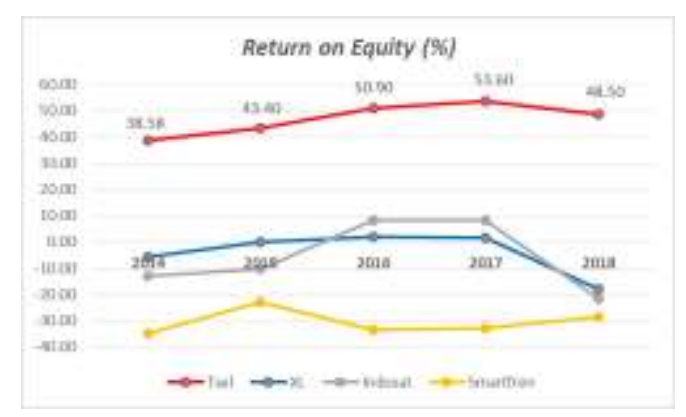

Gambar 12. Indikator ROE Industri Telekomunikasi (2014-2018)

Sumber : Laporan keuangan tahunan (data diolah)

Return on equity (ROE) adalah jumlah imbal hasil dari laba bersih terhadap ekuitas dan dinyatakan dalam bentuk persen. ROE digunakan untuk mengukur kemampuan suatu badan usaha dalam menghasilkan laba dengan bermodalkan ekuitas yang sudah diinvestasikan pemegang saham.

Tabel 9. Indikator ROE Industri Telekomunikasi (2014-2018)

\begin{tabular}{|l|r|r|r|r|r|}
\hline \multicolumn{1}{|c|}{ Data } & \multicolumn{1}{c|}{$\mathbf{2 0 1 4}$} & \multicolumn{1}{c|}{$\mathbf{2 0 1 5}$} & \multicolumn{1}{c|}{$\mathbf{2 0 1 6}$} & \multicolumn{1}{c|}{$\mathbf{2 0 1 7}$} & \multicolumn{1}{c|}{$\mathbf{2 0 1 8}$} \\
\hline Rata - rata & -3.75 & 2.49 & 6.83 & 7.68 & -4.88 \\
\hline Standar Deviasi & 26.68 & 24.95 & 30.03 & 30.72 & 31.05 \\
\hline Minimum & -34.81 & -22.86 & -33.64 & -32.70 & -28.50 \\
\hline Maksimum & 38.58 & 43.40 & 50.90 & 53.60 & 48.50 \\
\hline
\end{tabular}

Sumber : Laporan keuangan tahunan (data diolah)

Dari gambar 12. diatas menunjukkan bahwah yang memiliki nilai Return on Equity yang paling rendah dari 2014-2018 adalah PT. Smartfren Telecom Tbk, sedangkan untuk PT Indosat Tbk dan PT XL Axiata Tbk mengalami naik turun ROE secara bergantian, pada tahun 2014 dan 2015 PT XL Axiata berada diatas PT Indosat Tbk, namun dua tahun berikutnya posisinya jadi berbalik, PT Indosat Tbk berada diatas PT XL Axiata. Secara umum PT 
Telekomunikasi Selular memiliki nilai Return on Equity nya yang stabil dan baik dari tahun 2014 sampai dengan 2018 yaitu di kisaran 35\% sampai dengan 48\%.

Dari tabel 9. diatas secara umum industri telekomunikasi selama 5 tahun terakhir terlihat bahwa nilai rata-rata tiap tahun cenderung fluktuatif bergantian positif dan negatif. Net Profit Margin

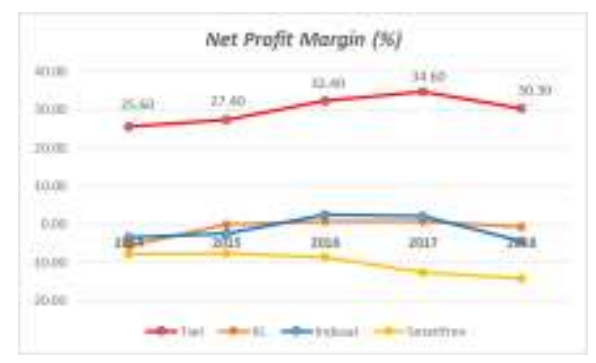

Gambar 13. Indikator NPM Industri Telekomunikasi (2014-2018)

\section{Sumber : Laporan keuangan tahunan (data diolah)}

Net Profit Margin (NPM) adalah rasio yang digunakan untuk menunjukkan kemampuan perusahaan dalam menghasilkan keuntungan bersih. Menurut Bastian dan Suhardjono (2006), rasio ini sangat penting bagi manajer operasi karena mencerminkan strategi penetapan harga penjualan yang diterapkan perusahaan dan kemampuannya untuk mengendalikan beban usaha. Menurut Weston dan Copeland (1998), semakin besar Net Profit Margin berarti semakin efisien perusahaan tersebut dalam mengeluarkan biaya-biaya sehubungan dengan kegiatan operasinya.

Tabel 10. Indikator NPM Industri Telekomunikasi (2014-2018)

\begin{tabular}{|l|r|r|r|r|r|}
\hline \multicolumn{1}{|c|}{ Data } & \multicolumn{1}{c|}{$\mathbf{2 0 1 4}$} & \multicolumn{1}{c|}{$\mathbf{2 0 1 5}$} & \multicolumn{1}{c|}{$\mathbf{2 0 1 6}$} & \multicolumn{1}{c|}{$\mathbf{2 0 1 7}$} & \multicolumn{1}{c|}{$\mathbf{2 0 1 8}$} \\
\hline Rata - rata & -9.87 & -6.88 & -4.01 & -7.27 & -15.14 \\
\hline Standar Deviasi & 26.96 & 28.85 & 31.49 & 35.73 & 33.13 \\
\hline Minimum & -46.68 & -51.74 & -54.28 & -64.70 & -64.70 \\
\hline Maksimum & 29.21 & 28.67 & 32.67 & 33.41 & 28.56 \\
\hline
\end{tabular}

Sumber : Laporan keuangan tahunan (data diolah)

Dari gambar 13. diatas menunjukkan bahwa yang memiliki nilai Net Profit Margin yang paling rendah dari 2014-2018 adalah PT. Smartfren Telecom Tbk, sedangkan untuk PT Indosat Tbk dan PT XL Axiata Tbk mengalami naik turun Net Profit Margin secara bergantian. Secara umum PT Telekomunikasi Selular memiliki nilai Return on Equity nya yang stabil dan baik dari tahun 2014 sampai dengan 2018 yaitu di kisaran 25\% sampai dengan 38\%, dengan nilai tertinggi di angka $34.60 \%$ pada tahun 2017. Dari tabel 10. diatas secara umum industri telekomunikasi selama 5 tahun terakhir terlihat bahwa meskipun nilai rata-rata tiap tahun meningkat, tetapi masih berada pada angka persentase negatif. Rata-rata NPM tertinggi juga masih negatif pada tahun 2016, yakni sebesar $-4.01 \%$.

\section{Kesimpulan}

Keseimpulan yang diperoleh dari analisa SCP di industri telekomunikasi yaitu perusahan yang memiliki pangsa pasar terbesar adalah PT Telekomunikasi Selular dengan nilai market share pada tahun 2019 adalah 52.97\%. 


\section{Annuridya Rosyidta Pratiwi Octasylva, Joko Rurianto}

Nilai CR4 untuk menentukan struktur pasar dari industri telekomunikasi. Berdasarkan data maka kita dapat melihat 4 perusahaan terbesar yang ada dalam industri ini memiliki pangsa pasar yang bervariasi dengan jumlah total yaitu 95,26\%. Sehingga dapat dikatakan struktur pasar industri telekomunikasi di Indonesia adalah oligopoli ketat, dengan nilai CR4 nya berada diantara $60 \%$ sampai dengan $100 \%$.. Karena beberapa produk dapat bersifat homogen maka pengambilan keputusan suatu perusahaan dapat berpengaruh bagi perusahaan lainnya, nilai MES industri telekomunikasi antara 46\% - 56\%.

Sesuai dengan strategi perilaku, hal-hal yang harus diperhatikan industri telekomunikasi adalah : penetapan harga lebih mudah, namun harus memperhatikan kemungkinan perang harga antar operator, memerlukan inovasi produk, PT Telekomunikasi Selular memiliki peringkat kualitas internet paling baik (dalam hal bitrate upload and browsing), kerjasama dengan pesaing dalam bentuk network sharing dan merger, promosi dan pemasaran yang tepat, analisa biaya investasi (CAPEX - OPEX), dengan nilai paling tinggi didapatkan oleh PT Telekomunikasi Selular (CAPEX 33.97\% tahun 2018); OPEX 46.21\% tahun 2014), dan nilai paling rendah didapatkan oleh PT Smartfren Telecom Tbk (CAPEX $1.29 \%$ tahun 2015); OPEX $1.42 \%$ tahun 2015) dan dalam hal kinerja perusahaan, dari data Return on Asset, Return on Equity, dan Net Profit Margin, PT Telekomunikasi Selular adalah perusahaan dengan kinerja profitabilitas paling baik dan stabil, walaupun dari data Debt to Equity Ratio nilainya paling tinggi dibandingkan perusahaan lain (kisaran 10\% - 20\%)

\section{Daftar Pustaka}

Adiningsih, Sri. 2007. "Persaingan Pada Industri Telepon Selular di Indonesia." Pusat Studi Asia Pasifik Universitas Gadjah Mada.

Axiata, XL. 2018. Annual Report 2014-2018. XL Axiata, Jakarta.

Badan Pusat Statistik. 2019. Statistik Telekomunikasi Indonesia 2018. Jakarta: BPS.

Bastian, Indra dan Suhardjono. 2006. Akuntansi Perbankan. Edisi 1. Jakarta: Salemba Empat.

Chiang, Y.H., Tang, B.S. dan Leung W.Y. 2001. Market Structure of the Construction Industri in Hongkong. Construction Management and Economics

Church, J., \& Ware, R. (2000). Industrial Organization A Strategic Approach. McGrawHill (Vol. 12).

Diallo, A., \& Tomek, G. (2015). The Interpretation of HH-Index Output Value When Used As Mobile Market Competitiveness Indicator. International Journal of Business and Management, 10(12), 48. https://doi.org/10.5539/ijbm.v10n12p48

Gaughan, P. A. (2002). Mergers, Acquisitions, and Corporate Restructurings. Wiley.

Hughes, Graham; Fill, Chris. Marketing Communications 2005-2006. Elsevier - Butterworth Heinemann: Oxford. 2005Indosat. 2018. Annual Report 2014-2018. Indosat, Jakarta.

Indriantoro, Nur dan Supomo, 2002, “ Metodologi Penelitian Bisnis Untuk Akuntansi dan Manajemen, Edisi Pertama, Yogyakarta : BPFE.

Jaya, Wihana Kirana. 2001. Ekonomi Industri: Konsep dasar, struktue peilaku dan kinerja pasar. Edisi 2, Yogyakarta. BPPE

GSM Association. (2012). Mobile Infrastructure Sharing. GSMA White Paper, (September), $1-23$.

Kumar, Y. (2015). Advantages and disadvantages of Mergers and Acquisition (M\&A). nPerf. 2018. Survey Report 2018

Smartfren. 2018. Annual Report 2014-2018. Smartfren, Jakarta.

Telkomsel. 2018. Annual Report 2014-2018. Telkomsel, Jakarta

Tereschuk, S. (2015). Network infrastructure sharing Drivers for network sharing. 
INOBIS: Jurnal Inovasi Bisnis dan Manajemen Indonesia

Volume 03, Nomor 03, Juni 2020

Annuridya Rosyidta Pratiwi Octasylva, Joko Rurianto

Tim Peneliti Puslitbang SDPPI (2018). Analisis Industri Telekomunikasi Indonesia Untuk Mendukung Efisiensi. Puslitbang Sumber Daya, Perangkat, dan Penyelenggaraan Pos dan Informatika Badan Penelitian dan Pengembangan SDM Kementerian Komunikasi dan Informatika

Weston dan Copeland (1998), Manajemen keuangan, Edisi 9. Jakarta: Erlangga 